С.С. Рязанцев ${ }^{1}$, В.С. Кадубенко ${ }^{2}$

${ }^{1}$ Харківський начіональний університет Повітряних Сил ім. І. Кожедуба, Харків

${ }^{2}$ Військова частина А2892, Володимир - Волинський

\title{
МЕТОДИ УПРАВЛІННЯ РОЗПОДІЛОМ ЕНЕРГЕТИЧНИХ (ЧАСОВИХ) РЕСУРСІВ БАГАТОФУНКЦІОНАЛЬНОЇ РЛС У РЕЖИМІ ВИЯВЛЕННЯ
}

В статті розглядається один з можливих напрямків підвищення ефективності інформаційних засобів сучасних та перспективних багатоканальних зенітних ракетних комплексів, щчо мають в своєму складі багатофункціональні радіолокаційні станиіі. Запропоновано необхідність змінити закладений в багатофункцііональну радіолокаційну станцію на етапі проектування, алгоритм бойової роботи який є незмінним в цุиклі роботи станиії і використовувати незадіяні тактові інтервали для реалізації інших показників режиму виявлення. Приведені аналітичні вирази для допошуку повітряних цілей в заданій області зони виявлення станиії. Приведені дослідження середнього значення та середнього квадратичного відхилення помилок $з$ пошуку повітряних цүілей в заданій області зони виявлення станції.

Ключові слова: багатофункиіональна РЛС, енергетичні (часові) ресурси, метод управління, режим виявлення.

\section{Вступ}

Постановка проблеми. Бойові дії на сході України характеризуються новими формами, характером ведення збройної боротьби та застосуванням новітніх зразків озброєння і техніки, які мають новий технічний рівень та продовжують стрімко розвиватись.

Враховуючи зміни характеру ведення збройної боротьби, а також інтенсивний розвиток перспективних зразків ЗРК у передових країнах світу, зазначені обставини зумовлюють актуальність керівництва Держави і 3С України продовжувати пошук ефективних напрямків підвищення боєздатності Збройних Сил України. Велике значення у цьому процесі безумовно має розробка і удосконалення засобів ЗРК (радіолокаційних станцій), що знаходяться на озброєнні ЗС України [1].

Усі країни світу пріоритет віддають багатофункціональним радіолокаційним станціям (БФ РЛС), в яких забезпечується та реалізовується активний супровід різнотипних цілей [4].

Основним напрямком робіт для цього є знаходження вирішення задачі оптимального керування енергетичним ресурсом БФ РЛС ЗРК у режимі виявлення повітряних цілей [10-12].

Під енергетичним ресурсом БФ РЛС розуміється сумарна кількість часових дискрет, що витрачається на виконання усіх радіолокаційних функцій у циклі їі роботи. У відповідності до цього, кількість часових дискрет, яка виділяється на реалізацію конкретної радіолокаційної функції, пропорційна кількості енергії, яку витрачає РЛС на реалізацію цієї функції [4].
Існуючі методи керування енергетичним ресурсом БФ РЛС не дозволяють у повній мірі використовувати можливості сучасних радіолокаційних станцій ЗРК, в тому числі й у режимі виявлення повітряних цілей. Вони, як правило, передбачають використання рівномірних параметрів цього режиму, тобто виділення однакового енергетичного ресурсу на проведення вимірів координат цілі і передачу команд керування декількома ракетами. До того ж послідовність проведення цих операцій у часі фіксована, що не завжди дозволяє вирішувати з належною ефективністю та точністю завдання, поставлені перед РЛС [7].

Отже, незмінний порядок функціонування БФ РЛС в реальних умовах бойової роботи приводить до зниження іiі потенційної пропускної спроможності і це може призвести до пропуску цілей без обстрілу зенітним ракетним комплексом (ЗРК), і як наслідок, невиконанню поставленого бойового завдання ЗРК і ще гірше знищенню прикриваємого об'єкту.

Таким чином, для подолання протиріч необхідно оптимізувати функціонування БФ РЛС та змінити закладений в БФ РЛС на етапі проектування, алгоритм бойової роботи, який є незмінним в циклі роботи станції.

Аналіз останніх досліджень і публікацій. Питанням оптимізації процесу функціонування БФ РЛС у режимі виявлення присвячено немало робіт [1-4]. Але, проведений аналіз літератури у цьому напрямку показав, що задача оптимального управління енергетичними (часовими) ресурсами БФ РЛС у режимі виявлення цілей потребує проведення подальших досліджень. 
Метою статті $\epsilon$ розробка методу управління розподілом енергетичних (часових) ресурсів БФ РЛС ЗРК у режимі виявлення (допошуку) та змінення закладеного в БФ РЛС на етапі проектування, алгоритму бойової роботи, який $є$ незмінним в циклі роботи станції.

\section{Виклад основного матеріалу}

Завдання управління енергетичними (часовими) ресурсами в режимі виявлення цілей у відомих роботах [6-7] вирішувалася виходячи 3 показників оптимальності виявлення та інформаційного показника для оцінки витрат енергетичних (часових) ресурсів БФ РЛС. Такий підхід об'єднує оцінку ефективності обраної стратегії огляду простору з оцінкою оптимального прийому сигналів, відбитих від цілей. Але, при використанні показників оптимальності виявлення та інформаційного показника значно ускладнюється визначення витрат енергетичних (часових) ресурсів на виявлення траєкторій цілей та їх траєкторне супроводження.

3 іншого боку, в ряді робіт [1;9] для характеристики ефективності роботи РЛС в режимі виявлення використовуються показники ефективності вторинної обробки, наприклад середній час захоплення цілі на супровід. Але, такі показники характеризують лише етап вторинної обробки радіолокаційної інформації і не враховуються витрати енергетичних (часових) ресурсів на пошук цілей.

Таким чином, показники ефективності функціонування БФ РЛС, які пов'язують витрати енергетичних (часових) ресурсів на етапі пошуку і виявлення невідомої кількості рухомих цілей, а також при виявленні і супроводі їх траєкторій, є невизначеним. Відповідно до цього, завдання управління енергетичними (часовими) ресурсами в режимі виявлення цілей, в якій враховані особливості функціонування станції на кожному з етапів на теперішній час $є$ невирішеною.

Отже, виникає необхідність змінити закладений в БФ РЛС на етапі проектування, алгоритм бойової роботи, який є незмінним в циклі роботи станції і використовувати незадіяні тактові інтервали для реалізації наступних показників режиму виявлення:

- зменшити максимальний час огляду БФ РЛС для виявлення повітряних цілей;

- збільшити ймовірність правильного виявлення;

- підвищити точність виявлення наведення більшої кількості ракет.

Виявлення повітряних цілей полягає в ухваленні рішення про наявність або відсутність цілей в кожній виділеній ділянці простору 3 мінімально допустимою вірогідністю помилкових рішень.

Вимір зводиться до вироблення оцінок коорди- нат і параметрів руху цілей 3 мінімально допустимими погрішностями.

Процес виявлення (допошуку) радіолокації повітряних цілей умовно можна розділити на три етапи [10]:

- пошук цілей;

- виявлення відбитих від цілей сигналів на тлі шуму;

- формування відміток радіолокаційних цілей і оцінка їх координат.

Під пошуком радіолокаційних цілей розуміється процес обстеження за допомогою БФ РЛС певної області простору, яка розбита на Q дозволених об'ємів, для забезпечення радіолокаційного контакту з ціллю на час, достатній для виявлення відбитого від неї сигналу із заданою вірогідністю при допустимому значенні вірогідності неправдивих тривог [3]. У сферичній системі координат дозволеними об'ємами $\epsilon$ область простору, розміри якої задаються роздільною здатністю БФ РЛС по дальності $\delta \gamma$ двома кутовими розмірами: роздільною здатністю БФ РЛС по азимуту $\delta_{\beta}$ і куту місця $\delta_{\varepsilon}$. По кутових координатах роздільна здатність визначається шириною приймальної діаграми спрямованості БФ РЛС, а по дальності - типом використовуваного сигналу [8]. Ескіз дозволених об'ємів представлений на рис. 1.

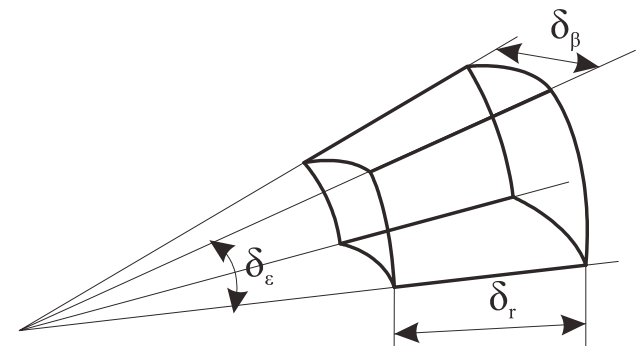

Рис. 1. Ескіз дозволених об'ємів Джерело: розроблено авторами за даними [9, С. 62].

Лінійні розміри дозволеного об'єму в картинній площині інформаційних засобів ЗРК (ЗРС) військ ППО СВ при веденні пошуку цілей, як правило, складають сотні метрів, а час, необхідний на зондування кутового напрямку, на якому знаходиться даний обсяг дозволу, становить частки секунди [5]. Отже, імовірність переміщення цілі з дозволеного об'єму за час його огляду мала. Тому, можна вважати, що ціль, з'явившись в деякому дозволеному об'єму, буде виявлена, перш ніж перейде в інший дозволений об'єм.

Цільова обстановка в зоні виявлення БФ РЛС характеризується просторово - часовим розподілом цілей [7]. Будемо вважати, що зона виявлення БФ РЛС розділена на кінцеве число пронумерованих дозволених об'ємів $q=1, Q$, за якими випадковим чином переміщується повітряна ціль.

Завданням БФ РЛС в умовах відсутності апріорної інформації $є$ прийняття рішення щодо наявнос- 
ті або відсутності цілей в кожному з дозволених об'ємів зони огляду.

3 цією метою необхідно за мінімально можливий час оглянути всі дозволені об'єми зони огляду.

При наявності апріорної інформації про розподіл цілей, що характерно для допошуку цілей по цілевказівки, завданням БФ РЛС є виявлення цілей за мінімальний час при заданому числі помилкових тривог і визначення координат із заданою точністю.

При отриманні цілевказівки від зовнішніх джерел радіолокаційної інформації за допомогою БФ РЛС, починаючи з моменту часу $t_{0}$, організовується до пошук повітряної цілі в заданій області зони виявлення. Відповідно до бойового алгоритму запрограмованого на етапі проектування за даними цілевказівки (азимут, кут місця і дальність цілі) станція виявлення цілі виробляє керуючі сигнали які забезпечують виведення нормалі ФАР в напрямку на ціль. Після установки нормалі ФАР СЦОМ організовує до пошук цілі в секторі $k$ градусів по азимуту i $k$ градусів по куту місця (всього $k \times k$ ) кутових напрямків) шляхом зміни кутового положення діаграми спрямованості ФАР іiі захоплення на автоматичний супровід обрану ціль. Ця область однозначно визначається через дозволені об'єми, які необхідно оглянути для виявлення повітряної цілі [7]. В $n$-му циклі управління БФ РЛС виділяється певна кількість ТІ, які визначають долю енергетичних (часових) ресурсів, що виділяються для реалізації допошуку повітряних цілей [12]. Ця частка енергетичних (часових) ресурсів в $n$-му циклі управління розподіляється за дозволеними об'ємами так, що, десь частка енергетичних (часових) ресурсів, що припадають на $q$-й дозволений об'єм в $n$-му циклі управління. Передбачається, що при реалізації допошуку по цілевказівці, відомо імовірнісний розподіл розташування цілі. Крім того, будемо припускати, що повітряна ціль неодмінно знаходиться в одному 3 дозволених об'ємів за якими призначений до пошук, тобто . На підставі даних цілевказівки необхідно так розподілити, щоб отримати максимум умовної імовірності виявлення повітряної цілі до заданого моменту часу (до кінця циклу управління).

Використовуючи фізичне явище, яке супроводжує процес виявлення, імовірність виявлення цілі запишемо в наступному вигляді: об'ємів;

Припустимо, $N \max (k \times k)$ матриця дозволених

Розрахунок пошуку однієї цілі $(k \times k)$ матриці дозволених об'ємів;

$$
K(M)=N \max +n_{i} \cdot M .
$$

Розрахунок пошуку двох цілей $(k \times k)$ матриці дозволених об'ємів;

$$
K(M)=N \max +n_{i} \cdot M+n_{i} \cdot M .
$$

Розрахунок пошуку $n$ цілей $(k \times k)$ матриці дозволених об'ємів;

$$
K(M)=N \max +\sum_{M=0}^{M}\left(M \cdot r n d\left(n_{i}\right)\right),
$$

де $N \max -(k \times k)$ матриця дозволених об'ємів;

$n_{i}$ - кількість об'ємів;

$M$ - кількість цілей;

$K(M)$ - функція пошуку цілей;

rnd(16) - псевдовипадкове число 3 рівномірним розподілом.

Виходячи 3 формули проведемо дослідження для допошуку 10 цілей ФАР в секторі $j$ градусів по азимуту на $j$ градусів по куту місця.

Прийняли:

$$
\begin{gathered}
N \max =16 ; n_{i}=1,2 . .16 ; M=0,1 . .10 ; \operatorname{rnd}(16) . \\
K(M)=16+\sum_{M=0}^{M}(10 \cdot \operatorname{rnd}(16)) .
\end{gathered}
$$

На рис. 2 наведені результати трьох досліджень допошуку 10 цілей ФАР в секторі $j$ градусів по азимуту на $j$ градусів по куту місця. Де показано імовірний час по кожному досліджені який потрібен ФАР для пошуку імовірних 10 цілей.

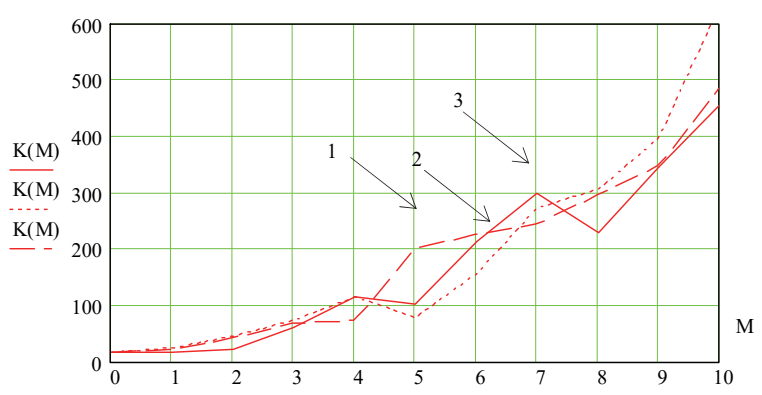

Рис. 2. Дослідження допошуку 10 цілей ФАР в секторі $j$ градусів по азимуту на $j$ градусів по куту місця

Джерело: розроблено авторами.

На рис. 2 крива 1 - перший результат досліджень допошуку 10 цілей ФАР в секторі $j$ градусів по азимуту на $j$ градусів по куту місця.

2 - другий результат досліджень допошуку 10 цілей ФАР в секторі $j$ градусів по азимуту на $j$ градусів по куту місця;

3 - третій результат досліджень допошуку 10 цілей ФАР в секторі $j$ градусів по азимуту на $j$ градусів по куту місця.

Проведемо дослідження для допошуку 10 цілей ФАР в секторі $q$ градусів по азимуту на $q$ градусів по куту місця.

Прийняли:

$N \max =9 ; n_{i}=1,2 . .9 ; M=0,1 . .10 ; \operatorname{rnd}(9)$. 


$$
K(M)=9+\sum_{M=0}^{M}(10 \cdot r n d(9)) .
$$

На рис. 3 наведені результати трьох досліджень допошуку 10 цілей ФАР в секторі $q$ градусів по азимуту на $q$ градусів по куту місця.

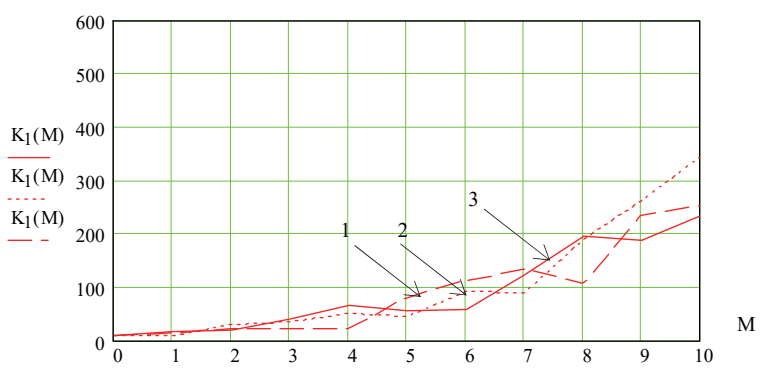

Рис. 3. Дослідження допошуку 10 цілей ФАР в секторі $q$ градусів по азимуту на $q$ градусів по куту місця

Джерело: розроблено авторами.

На рис. 3 крива 1 - перший результат досліджень допошуку 10 цілей ФАР секторі $q$ градусів по азимуту на $q$ градусів по куту місця.

2 - другий результат досліджень допошуку 10 цілей ФАР секторі $q$ градусів по азимуту на $q$ градусів по куту місця;

3 - третій результат досліджень допошуку 10 цілей ФАР в секторі $q$ градусів по азимуту на $q$ градусів по куту місця.

На рис. 4 проведено порівняння середніх досліджень допошуку 10 цілей ФАР в секторі $j$ градусів по азимуту на $j$ градусів по куту місця та в секторі $q$ градусів по азимуту на $q$ градусів по куту місця. Де показано імовірний виграш часу по середньому із досліджень для пошуку імовірних 10 цілей.

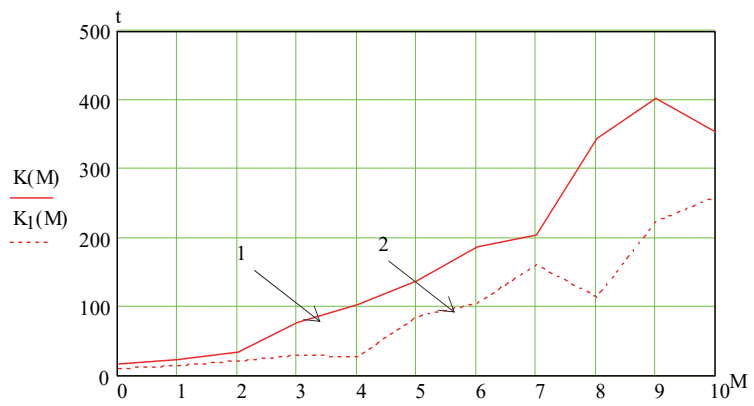

Рис. 4. Порівняння середніх досліджень допошуку 10 цілей ФАР в секторі $j$ градусів по азимуту на $j$

градусів по куту місця та в секторі $q$ градусів

по азимуту на $q$ градусів по куту місця

Джерело: розроблено авторами.

На рис. 4 крива 1 - дослідження допошуку 10 цілей ФАР у секторі $j$ градусів по азимуту на $j$ градусів по куту місця;
2 - дослідження допошуку 10 цілей ФАР у секторі $q$ градусів по азимуту на $q$ градусів по куту місця.

Розрахунок середнього значення функції пошуку цілей $K(M)$ та $K_{1}(M)$ і середнього квадратичного відхилення помилки функції пошуку цілей $K(M)$ та $K_{1}(M)$ :

$$
\begin{gathered}
m(n, M)=\frac{1}{n} \sum_{i=1}^{n} K(M) ; \\
m_{1}(n, M)=\frac{1}{n} \sum_{i=1}^{n} K_{1}(M) ; \\
\sigma\left(n_{i}, M\right)=\sqrt{\frac{1}{n_{i}} \sum_{i=1}^{n_{i}} K(M)-\left(m\left(n_{i}, M\right)\right)^{2}} ; \\
\sigma_{1}\left(n_{i}, M\right)=\sqrt{\frac{1}{n_{i}} \sum_{i=1}^{n_{i}} K_{1}(M)-\left(m_{1}\left(n_{i}, M\right)\right)^{2}},
\end{gathered}
$$

де $m\left(n_{i}, M\right)$-середнє значення функції пошуку цілей $K(M)$;

$m_{1}\left(n_{i}, M\right)$ - середнє значення функції пошуку цілей $K(M)$;

$\sigma\left(n_{i}, M\right)$-середне квадратичне відхилення помилки функції пошуку цілей $K_{1}(M)$;

$\sigma_{1}\left(n_{i}, M\right)$ - середнє квадратичне відхилення помилки функції пошуку цілей $K_{1}(M)$;

$n_{i}$ - кількість об'ємів;

$M$ - кількість цілей;

$K(M)$ - функція пошуку цілей.

На рис. 5 наведені результати досліджень середнього значення допошуку 10 цілей та результаты досліджень середнього квадратичного відхилення помилок функції пошуку цілей $K(M)$ та помилок функції пошуку цілей $K_{1}(M)$.

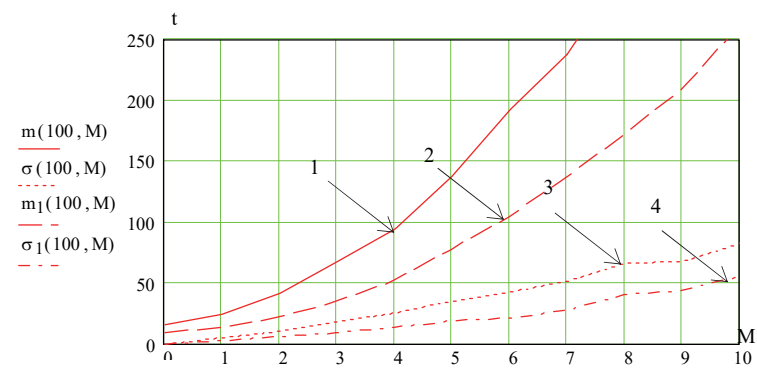

Рис. 5. Дослідження середнього значення та середнього квадратичного відхилення помилок 3 пошуку цілей функції пошуку цілей $K(M)$ та функції пошуку цілей $K_{1}(M)$ Джерело: розроблено авторами.

На рис. 5 крива 1 - результат досліджень середнього значення допошуку 10 цілей ФАР секторі $q$ градусів по азимуту на $q$ градусів по куту місця; 
2 - результат досліджень середнього значення допошуку 10 цілей ФАР секторі $j$ градусів по азимуту на $j$ градусів по куту місця;

3 - результат досліджень середнього квадратичного відхилення помилок допошуку 10 цілей ФАР в секторі $j$ градусів по азимуту на $j$ градусів по куту місця;

4 - результат досліджень середнього квадратичного відхилення помилок допошуку 10 цілей ФАР в секторі $q$ градусів по азимуту на $q$ градусів по куту місця.

Таким чином один 3 можливих методів вирішення задачі оптимального керування енергетичним ресурсом БФ РЛС ЗРК у режимі виявлення повітряних цілей це зміна сектору до пошуку, який запрограмований на етапі проектування.

За результатами порівняльного аналізу допошуку 10 цілей ФАР в секторі $q$ градусів по азимуту на $q$ градусів по куту місця це вираз (4), та секторі $j$ градусів по азимуту на $j$ градусів по куту місця це вираз (5), показано імовірний виграш часу по середньому із досліджень для пошуку імовірних 10 цілей, проведено розрахунок середнього значення функції пошуку цілей це вираз (6) та (7), проведено розрахунок середнього квадратичного відхиленняпомилки функції пошуку цілей, який розглянутий в даній роботі це вираз (8) та (9).

\section{Висновки}

За результатами проведеного аналізу оптимального сектору допошуку повітряної цілі в заданій області зони виявлення станції можливо зробити висновок, що запрограмований на етапі проектування допошук цілі в секторі $k$ градусів по азимуту і $k$ градусів по куту місця (всього $(k \times k)$ кутових напрямків) займає більше часу та витрати енергетичних (часових) ресурсів ніж допошук цілі ФАР в секторі $q$ градусів по азимуту на $q$ градусів по куту місця.

Реалізація запропонованого методу управління розподілом енергетичних (часових) ресурсів БФ РЛС ЗРК у режимі виявлення (допошуку) дозволяє заощадити енергетичні ресурси станції, зменшити максимальний час огляду БФ РЛС, збільшити імовірність правильного виявлення та здійснювати наведення більшої кількості ракет.

\section{Список літератури}

1. Шамко В.С. Розвиток форм і способів застосування Повітряних Сил Збройних Сил України в сучасних умовах ведення збройної боротьби / В.С. Шамко, О.М. Жарик, В.В. Коваль // Наука і техніка Повітряних Сил Збройних Сил України. - 2018. - № 2(31). - С. 9-15. https://doi.org/10.30748/nitps.2018.31.01.

2. Камалтинов Г.Г. Тенденції розвитку радіолокаційних засобів контролю повітряного простору / Г.Г. Камалтинов, О.М. Колеснік // Збірник наукових праць Харківського національного університету Повітряних Сил. - 2020. - № 2(64). C. 89-95. https://doi.org/10.30748/zhups.2020.64.13.

3. Алексеев Я. Состояние и перспективы развития зарубежных ЗРК большой и средней дальности / Я. Алексеев, О. Данилов // Зарубежное военное обозрение. - 2006. - № 11. - С. 35-43. http://pentagonus.ru/publ/6-1-0-170.

4. Кузьмин С.3. Цифровая радиолокация. Введение в теорию / С.3. Кузьмин. - К.: КВІЦ, 2000. - 428 с. https://www.twirpx.com/file/347979/.

5. Аналіз особливостей побудови і застосування перспективних систем управління високоточною зброєю. Системи позиціонування / А.Б. Скорик, О.Д. Флоров, Є.В. Моргун, Д.В. Молчанов, О.В. Гречка, С.М. Шепелевич // Наука $\mathrm{i}$ техніка Повітряних Сил Збройних Сил України. - 2018. - № 4(33). - С. 43-51. https://doi.org/10.30748/ nitps.2018.33.06.

6. Помогаєв І.В. Удосконалений спосіб напівактивного самонаведення зенітних керованих ракет з вимірюванням дальності ракета-ціль. / І.В. Помогаєв, В.А. Таршин, А.Б. Скорик // Наука і техніка Повітряних Сил Збройних Сил України. - 2020. - № 4(41). - С. 95-101. https://doi.org/10.30748/nitps.2020.41.11.

7. Решетник В.М. Проблемы управления ЗРК / В.М. Решетник, М.К. Можар, И.Ю. Гришин // Наука і оборона. 1994. - № 4. - С. 25-32. http://nbuv.gov.ua/j-pdf/recs_2009_3_6.pdf.

8. Ширман Я.Д. Радиоэлектронные системы: Основы построения и теория. Справочник. Изд. 2-е, перераб. и доп. / Я.Д. Ширман. - М.: Радиотехника, 2007. - 512 c. https://www.twirpx.com/file/85124/.

9. Шишов Ю.А. Многоканальная радиолокация с временным разделением каналов / Ю.А. Шишов, В.А. Ворошилов. - М.: Радио и связь, 1987. - 114 c. https://www.twirpx.com/file/296034/.

10. Саврасов Ю.С. Алгоритмы и программы в радиолокации / Ю.С. Саврасов. - М.: Радио и связь, 1985. - 216 с. https://www.twirpx.com/file/296029/.

11. Мегельбей В.В. Обоснование частного показателя эффективности затрат энергетического ресурса при реализации режима обнаружения воздушных целей многофункциональной РЛС зенитного ракетного комплекса / В.В. Мегельбей, С.В. Кадубенко, А.В. Мегельбей // Збірник наукових праць Харківського університету Повітряних Сил. - 2009. № 1(19). - C. 60-66. http://www.hups.mil.gov.ua/periodic-app/article/3886.

12. Кадубенко С.В. Метод оптимального управления режимом наведения многофункциональной РЛС / С.В. Кадубенко, А.В. Круглов, О.Л. Смирнов // Збірник наукових праць Харківського авіаційного інституту. - 2001. - № 21. - С. 47-53. 


\section{Відомості про авторів:}

\section{Рязанцев Сергій Сергійович}

викладач Харківського національного університету Повітряних Сил ім. І. Кожедуба, Харків, Україна https://orcid.org/0000-0003-3049-2547

Кадубенко Валентин Станіславович начальник зенітної ракетної обслуги військова частина А2892, Володимир-Волинський, Україна https://orcid.org/0000-0001-7709-6619

\section{Information about the authors:}

\section{Serhii Riazantsev}

Instructor of Ivan Kozhedub Kharkiv National

Air Force University,

Kharkiv, Ukraine

https://orcid.org/0000-0003-3049-2547

Valentin Kadubenko

Chief of Anti-Aircraft Missile Crews

Military Base A2892

Vladimir Volynsky, Ukraine

https://orcid.org/0000-0001-7709-6619

\title{
МЕТОДЫ УПРАВЛЕНИЯ РАСПРЕДЕЛЕНИЕМ ЭНЕРГЕТИЧЕСКИХ (ВРЕМЕННЫХ) РЕСУРСОВ МНОГОФУНКЦИОНАЛЬНОЙ РЛС В РЕЖИМЕ ОБНАРУЖЕНИЯ
}

\author{
С.С. Рязанцев, В.С. Кадубенко
}

В статье рассматривается одно из возможных направлений повышения эффективности информационных средств современных и перспективных многоканальных зенитных ракетных комплексов, которые имеют в своем составе многофункииональные РЛС. Предложена необходимость изменить заложенный в БФ РЛС на этапе проектирования, алгоритм боевой работы, который является неизменным в ичикле работы станции и использовать незадействованные тактовые интерваль для реализачии других показателей режима обнаружения. Приведены аналитические выражения для поиска воздушных иелей в заданной области зоны обнаружения станции. Приведены исследования среднего значения и среднего квадратичного отклонения ошибок по поиску воздушных иелей в заданной области зоны обнаружения станции.

Ключевые слова: многофункииональная РЛС, энергетические (временные) ресурсы, метод управления, режим обнаружения.

\section{METHODS OF MANAGEMENT ALLOCATION OF POWER (SENTINELS) RESOURCES OF MULTIFUNCTION RADAR IN MODE OF EXPOSURE}

\author{
S. Riazantsev, V. Kadubenko
}

One of possible directions of increase of efficiency of informative facilities of modern and perspective multichannel antiaircraft missile systems that have in the composition multifunction radar is examined in the article. Existent methods of management the power resource of multifunction radar does not allow in a complete measure to use possibility of the modern radiolocation stations of anti-aircraft missile systems, including in the mode of exposure of air aims. They, as a rule, envisage the use of even parameters of this mode, id est a selection of identical power resource is on realization of measuring of coordinates of aim and transmission of commands of management a few rockets. Besides the sequence of realization of these operations in time is fixed, that not always allows to decide with the proper efficiency and exactness the tasks put before radar. Thus, unchanging order of functioning of multifunction radar in the real terms of battle work results in the decline of her potential carrying capacity and it can result in admission of aims without a fire by a zenithal rocket complex (anti-aircraft missile systems), and as a result, to non-fulfillment of the put combat mission of anti-aircraft missile systems and it worse to elimination of building protection. Thus, for overcoming of contradictions it is necessary to optimize functioning of necessity to change stopped up in multifunction radar on the stage of planning offers, algorithm of battle work that is unchanging in the loop of work of the station and to use the uninvolved time intervals for realization of other indexes of the mode of discovery. Analytical expressions over are brought for the search of air aims in the set area of zone of finding out the station. Researches over of mean value and standard deviation of errors are brought on the search of air aims in the set area of zone of finding out the station.

On results the conducted analysis an optimal sector is to the search of air aim in the set area of zone of exposure of the station, came to the conclusion that programed on the stage of planning to the search of aim in the sector of $k$ degrees for azimut and $k$ degrees on the corner of place(all $k \times k$ of angular directions) occupies more than time and charges of power(sentinels) resources than to search of aim of headlights in the sector of $q$ degrees on an azimuth on $q$ degrees on the corner of place.

Keywords: multifunction radar, power (temporal) resources, management method, detection mode. 